\title{
Jødisk mangfold i norske KRLE-lærebøker?
}

\author{
Av Tyson Herberger og Anders Aschim
}

I hvilken grad kommer mangfoldet innen jødedommen til uttrykk $i$ norske larebøker $i$ KRLE? Artikkelen undersøker framstillingen av jøder og jødedom i tre mye brukte loereverk for grunnskolens ungdomstrinn, med utgangspunkt $i$ sporsmålet om representasjon, slik det er definert i Robert Jacksons fortolkende tilnarming til religionsundervisning. Selv om indre mangfold i noen grad tematiseres eksplisitt $i$ bokene, finner vi at det scrlig er bestemte grupper som fär representere jødedommen i tekst og illustrasjoner. Begrepene ortosentrisme og askenormativitet brukes for å karakterisere framstillinger som gir henholdsvis ortodoks og askenasisk jødedom en hegemonisk posisjon.

Nøkkelord: jødedom, mangfold, KRLE, lærebøker, ungdomstrinnet

Tyson Herberger (f. 1978), stipendiat, Høgskolen i Innlandet, Pb. 400, 2418 ELVERUM.

Epost: tyson.herberger@inn.no

Anders Aschim (f. 1958), professor, Hogskolen i Innlandet, Pb. 400, 2418 ELVERUM.

Epost: anders.aschim@inn.no

\section{INNLEDNING}

Kontekst: Religionsmangfold i grunnskolens religions- og livssynsfag

Først med mønsterplanen for grunnskolen av 1987 ble andre religioner enn kristendommen uttrykkelig, om enn marginalt, tematisert i læreplanene og lærebøkene i kristendomskunnskap (Winje, 2011, s. 140; Skjelbred et al., 2017, s. 306). Sporadiske referanser forekom riktignok også i eldre lærebøker, men da knyttet til framstillinger av kristen misjon, for jødedommens del også til bibelhistorien. For øvrig var emnet plassert under samfunnsfag.

Med innføringen av et felles religions- og livssynsfag i 1997 ble religionsmangfold et sentralt element i faget (Skjelbred et al., 2017, s. 307-312). Allerede i den første læreplanen for faget KRL var det presisert at elevene på ungdomstrinnet skulle få kunnskap om «ulike retninger innen jødedom (ortodoksi, konservativ jødedom, reformjødedom, sekulær jødedom)», og tilsvarende for islam, hinduisme og buddhisme (Kirke- utdannings- og forskningsdepartementet, 1996, s. 104).

I læreplanen i KRLE for Kunnskapsløftet (LK06) var et av kompetansemålene for ungdomstrinnet at eleven skulle kunne «gi en oversikt over mangfoldet i jødedommen, viktige historiske hendelser og jødedommens stilling i Norge og verden i dag» (Utdanningsdirektoratet, 2015). I læreplanene for fagfornyelsen

Prismet - IKO-Forlaget 2020

Tilgjengelig på https://journals.uio.no/index.php/prismet. Publisert under CC BY-NC 4.0. 
er ikke kompetansemålene like spesifikke. Men på overordnet nivå heter det i beskrivelsen av «Kjennskap til religioner og livssyn», et av kjerneelementene $\mathrm{i}$ KRLE-faget:

Faget skal gi kunnskap om og forståelse for kristendom og andre religioner og livssyn lokalt, nasjonalt og globalt og på individ-, gruppe- og tradisjonsnivå. Elevene skal også få innsikt $i$ hvordan kristendom og andre religioner og livssyn inngår $i$ historiske prosesser og henger sammen med samfunnsendringer og kulturarv. Elevene skal bli kjent med mangfoldet av religioner og livssyn, og med de ulike tradisjonenes indre mangfold. Faget skal gi grunnlag for refleksjon over majoritets-, minoritets- og urfolksperspektiver i Norge (Utdanningsdirektoratet, 2020).

Kompetansemålene har gradvis blitt mer generelle, men det er et gjennomgående trekk at elevene skal bli kjent med indre mangfold innen jødedom og andre religiøse tradisjoner. Dette er utfordrende både for lærere og for utviklere av læremidler. Tiden og plassen som er til disposisjon, gjør avgrensing og utvalg av stoff til en sentral, men vanskelig oppgave. Selv om lærebokas hegemoni i stadig større grad utfordres av digitale ressurser, er det mye som tyder på at lærebøker fremdeles er en av de viktigste faktorene som styrer religions- og livssynsundervisningen i norsk grunnskole (jf. Bråten, 2014; Tallaksen \& Hodne, 2014).

\section{Problemstilling}

Hvordan framstilles det indre mangfoldet i jødedommen i norske lærebøker i KRLE for ungdomstrinnet? Dette er denne artikkelens problemstilling. Den kan operasjonaliseres i to forskningsspørsmål:

1 Hvordan tematiseres indre mangfold i jødedommen eksplisitt i de mest brukte lærebøkene i faget?

2 Hvem får - og hvem får ikke - representere jødedommen i de generelle beskrivelsene av religionen i disse lærebøkene?

Tidligere forskning: Indre religionsmangfold i lærebøker Norsk og internasjonal forskning på læremidler i religions- og livssynsfag er omfattende (jf. Lewis \& Andreassen, 2014; Thomas \& Rolin, 2019, s. 42). Et funn som går igjen i mange lærebokanalyser, er en tendens til generalisering og essensialisering av religioner, forstått som monolittiske systemer. Dette har gjerne vært knyttet til det såkalte «verdensreligionsparadigmet», som mye nyere religionsvitenskap vil erstatte med en sterkere vektlegging av «levd (hverdags)religion» (Anker, 2017). 
En bred undersøkelse av britiske læremidler har funnet mange gode eksempler på framstillingen av indre mangfold i religiøse tradisjoner. Den påpeker likevel problemer på tre områder, nemlig når det gjelder religiøst mangfold, etnisk/ kulturelt mangfold, og kjønn (Jackson et al., 2010, s. 97-98; Wintersgill, 2014). I Norge har Suzanne Thobro undersøkt framstillingen av hinduisme og buddhisme i lærebøker for videregående skole. Mens buddhisme «fremstilles gjennomgående som å ha en essensiell kjerne, en autentisk og opprinnelig buddhisme, som mangfoldet innenfor buddhistisk praksis er mer eller mindre i kontakt med», er hinduisme framstilt «som en heterogen og inkluderende størrelse» (Thobro, 2008, s. 106). Et forskningsprosjekt ved Universitetet i Oslo intervjuet unge buddhister, hinduer og muslimer og sammenlignet deres oppfatning av sin religiøse tradisjon med framstillingen i lærebøker for videregående skole. En fant tydelige forskjeller mellom lærebøkenes «systematic and monolithic presentation» av religioner som «distinct and clearly defined traditions», og informantenes erfarings- og praksisbaserte refleksjoner (Gundersen et al., 2014, 13-14). Ann Midttun, som har undersøkt framstillingen av islam i en eldre utgave av et norsk læreverk for ungdomstrinnet, finner en tydelig tendens til generalisering: «Selv om det sies at det finnes ulike retninger blant muslimer i Norge, så vektlegges likevel en enhetlig praksis der muslimer fremstilles mer som en gruppe» (Midttun, 2014, s. 336).

Så vidt vi kan se, foreligger det ikke lignende undersøkelser av framstillinger av jødedommen. Innføringen av ny læreplan er også en anledning til et fornyet blikk på læremidlene i faget.

Teoretisk perspektiv: Representasjon

Fagfornyelsens KRLE-læreplan er sterkt påvirket av den britiske utdanningsforskeren Robert Jackson og hans «fortolkende tilnærming» til religionsundervisning (Jackson, 1997, 2004, 2017), utviklet på bakgrunn av etnografisk arbeid i det flerreligiøse Storbritannia og videreført i en rekke omfattende internasjonale forskningsprosjekter, også med norsk deltakelse. Sentrale elementer i denne tilnærmingen er sammenfattet i begrepene representasjon, fortolkning og refleksivitet (Jackson, 2004, s. 4). Formuleringen «individ-, gruppe- og tradisjonsnivå» i KRLE-læreplanens kjerneelement «Kjennskap til religioner og livssyn» er åpenbart inspirert av Jacksons representasjonsmodell:

[...] a model for representing religious material which encourages an exploration of the relationship between individuals in the context of their religio-cultural groups and the wider religious tradition to which they relate. The tradition is seen as a tentative whole, but the contested nature of that whole is recognised: for example, different insiders (as well as different outsiders) might have varying understandings of the nature and scope of, say, the Christian or Hindu traditions. The model encourages a 
view of religions which acknowledges their complexity, internal diversity, and their varying interactions with culture. It especially emphasizes the personal element in religions, seeing religion as part of lived human experience. However, the approach is not relativistic with regard to truth, aiming for a procedural epistemological openness and acknowledging varying and often competing truth claims (Jackson, 2004, s. 4; jf. Jackson, 1997, s. 64-69).

Med utgangspunkt i denne modellen vil vi i denne artikkelen særlig fokusere på mellomnivået, «religio-cultural groups».

\section{Materiale og metode}

Materialet for denne undersøkelsen er de tre mest brukte læreverkene i KRLE for ungdomstrinnet. KRLE-boka 8-10 (Wiik \& Waale, 2016) er nyeste utgave av et læreverk som samler lærestoffet for ungdomstrinnet i ett bind. Det samme gjør den nyeste utgaven av Store spørsmål (Hove, Jørgensen, Sandboe \& Rasmussen, 2020), det eneste læreverket som foreløpig er oppdatert etter fagfornyelsen. Det er dermed interessant å sammenligne denne med forrige utgave. Her hadde Store spørsmål separate lærebøker for hvert årstrinn. Jødedommen ble behandlet både på 8. og 10. klassetrinn (Hove et al., 2015, 2017). Horisonter har også separate lærebøker for hvert årstrinn. Her er jødedommen behandlet i boka for 8. klassetrinn og på noen sider i boka for 10. trinn (Holth \& Deschington, 2006; Holth \& Kallevik, 2008 , s. 232-233). Siden forlagene prioriterer de store skolefagene når det gjelder utviklingen av nytt materiell, og det i mange skoler er en viss treghet $i$ utskiftingen av lærebøker, er det grunn til å tro at de nåværende utgavene vil prege undervisningen i flere år ennå. Undersøkelsen begrenser seg til elevbøkene. Den omfatter ikke bare teksten i lærebøkene, men også materiale som illustrasjoner, kart og elevoppgaver.

Undersøkelsen bygger på nærlesing av avsnittene om jødedommen i de tre læreverkene. Materialet ble kodet og kategorisert med tanke på representasjon av grupper ut fra to akser, denominasjoner og kulturelle/geografiske grupper. Disse introduseres i neste avsnitt. Kodingen har altså vært tematisk og deduktiv, med utgangspunkt i Jacksons modell for representasjon og funn fra tidligere forskning om representasjon av indre religionsmangfold i lærebøker. En slik framgangsmåte løper risikoen «som en roper i skogen, får en svar»: En finner det en forventer å finne, for eksempel mangelfull representasjon av indre religiøst mangfold, mens aspekter ved materialet som kan peke i andre retninger går under radaren. På den annen side, i beste fall kan en analyse med et slikt utgangspunkt avdekke oversette eller utelatte fakta eller perspektiver. 


\section{JøDISK MANGFOLD}

Det interne mangfoldet innen jødedommen har mange aspekter, men to akser fanger inn særlig sentrale variasjoner.

For det første skjelner en gjerne mellom ulike denominasjoner (hebraisk: zeramim, entall: zerem) innen jødedommen, med forskjellige oppfatninger om hva som er rett observans. Vi velger å bruke begrepet «denominasjon» framfor alternativer som «trosretning» eller «konfesjon», som vi oppfatter som farget av en protestantisk-kristen religionsforståelse. Den første KRL-læreplanen nevnte flere av disse, nemlig ortodoks, konservativ og reform-jødedom, i tillegg til - interessant nok - sekulær jødedom. I senere år har det vært mye oppmerksomhet om såkalte ultra-ortodokse grupper (hebraisk: haredim). Dette er en noe upresis betegnelse som dekker et bredt spekter av grupperinger innen den ortodokse tradisjonen. Den hasidiske Chabad-retningen regnes ofte blant disse.

De jødiske menighetene i Oslo og Trondheim er begge registrert som trossamfunn. Menighetene har stort sett vært betjent av ortodokse rabbinere, men de er åpne for medlemmer av ulik observans. Også Chabad-retningen har aktiviteter i Norge, organisert av en Chabad-rabbiner og hans familie som er bosatt i Oslo, men de har ikke registrert seg som trossamfunn. Videre har også ikke-ortodokse retninger tilhengere i Norge, som møtes noen ganger til bønn og andre arrangementer, men uten organiserte menigheter. For eksempel har en Oslo-basert norsk kvinne som er ordinert som rabbiner innen retningen «Jewish Renewal» (en nyere ikke-ortodoks bevegelse som vektlegger spiritualitet), ledet en rekke slike arrangementer og gudstjenester.

For det andre har jøder gjennom historien, delvis på grunn av tvungen migrasjon, slått seg ned i ulike hjørner av verden. På bakgrunn av denne geografiske spredningen finnes det også et betydelig etnisk og kulturelt mangfold innen jødedommen. Ofte opererer en med to eller tre hovedgrupper (hebraisk: eidot, entall: eidah). Askenasiske jøder har historisk bakgrunn fra fransk- og tysktalende områder, men med senere tyngdepunkt i Øst-Europa. Sefardiske jøder ble fordrevet fra Spania og Portugal; mange slo seg ned i middelhavsområdet, noen andre steder i Europa, ikke minst $\mathrm{i}$ Nederland. Såkalte «portugisjøder» kom også til Danmark og Norge. Mizrahiske jøder fra Midt-Østen og Nord-Afrika regnes i noen framstillinger blant de sefardiske. Men det interne mangfoldet innen disse hovedgruppene er betydelig, og i tillegg finnes en rekke mindre grupper, som Beta Israel fra det etiopiske høylandet, malebariske jøder fra Sør-India og forskjellige andre eidot fra Italia til Kina.

De organiserte jødiske menighetene i Norge er, og har historisk sett vært, askenasisk dominert. Men det fantes portugisjødiske innvandrere alt før menighetene ble grunnlagt, og med økt globalisering i senere år har jøder med ulike bakgrunner bosatt seg i Norge og tatt aktiv del i det jødiske livet her. Blant annet har det jødiske samfunnet i Norge en høy andel israelske innvandrere (DellaPergola \& Staetsky, 2020, s. 42-43). 


\section{HVORDAN PRESENTERES INDRE JØDISK MANGFOLD \\ EKSPLISITT I L $Æ R E B Ø K E N E ?$}

Både Horisonter og KRLE-boka behandler ulike denominasjoner mot slutten av presentasjonen av jødedommen (Holth \& Deschington, 2006, s. 63-64; Wiik \& Waale, 2016, s. 252-255). Den forrige utgaven av Store spørsmål hadde ingen referanse til denominasjoner i hovedpresentasjonen i boka for 8. trinn, men to sider i repetisjonen av jødedommen i boka for 10. trinn (Hove et al., 2017, s. 211-212). Den nye ettbindsutgaven Store sporsmål 8-10 er den eneste som introduserer denominasjoner i første halvdel av framstillingen av jødedommen (Hove et al., 2020, s. 77).

En nøkkeldistinksjon mellom de ulike retningene er forholdet til halaka eller tradisjonell praksis i rabbinsk jødedom. Store spørsmål 8 sier: «Noen lever strengt etter lovene i religionen, andre mener lovene kan tilpasses et mer moderne liv» (Hove et al., 2015, s. 121). Men da overses oppfatninger i mer liberale retninger om at halaka ikke er bindende, er erstattet av sekulær moral, eller lignende. Bøkene nevner riktignok at «ortodoks jødedom» er et sammensatt fenomen, men ortodoks og ultra-ortodoks jødedom presenteres likevel som to uavhengige monolittiske størrelser. Horisonter 8 er det eneste unntaket. Her brukes ikke ordet ultra-ortodoks, men fenomenet beskrives i rammen av ortodoks jødedom på en måte som åpner for variasjon innen den ortodokse retningen (Holth \& Deschington, 2006, s. 63).

Ingen av bøkene nevner Chabad-retningens nærvær i Norge. De inkluderer heller ikke mindre retninger som «Jewish Renewal» eller Rekonstruksjonistisk jødedom. KRLE-boka har riktignok et foto av Lynn Feinberg, en kvinnelig norsk rabbiner som er ordinert innen rammen av «Jewish Renewal» (Wiik \& Waale, 2016, s. 254), og Horisonter 8 nevner at det finnes andre denominasjoner (Holth \& Deschington, 2006, s. 63). Men slike retninger nevnes ikke ved navn.

Store Spørsmål og Horisonter 8 omtaler den spansk-jødiske «gullalderen» og utdrivelsen i 1492, men uten å nevne at en spansk-jødisk diaspora-identitet består til denne dag (Holth \& Deschington, 2006, s. 56, 61; Hove et al., 2015, s. 129-130). Betegnelser som askenasisk, sefardisk eller mizrahisk er aldri brukt. Riktignok nevner både Horisonter og KRLE-boka de geografiske utgangspunktene for retningene de diskuterer (Holth \& Deschington, 2006, pp. 63-64; Wiik \& Waale, 2016, pp. 252-254), men ingen av dem knytter disse bevegelsene til etniske identiteter. Siden begrepet askenasisk ikke er nevnt, blir det heller ikke tydelig at oppdelingen i denominasjoner primært er et askenasisk fenomen.

\section{HVILKE DENOMINASJONER FÅr REPRESENTERE DET JØDISKE?}

Dette spørsmålet belyser vi ut fra tre temaer: Spørsmålet om hvem som er jødisk, mattradisjoner og sabbaten. Disse temaene skilte seg ut under kodingen fordi de 
er sentrale i alle bøkenes presentasjoner, og fordi det er betydelig variasjon mellom jødiske denominasjoner på disse feltene.

\section{Hvem er jøde?}

Både Horisonter $8, K R L E$-boka og Store spørsmål 8 innleder presentasjonen av jødedommen med definisjoner av hvem som regnes som jødisk. Alle gjengir den tradisjonelle ortodokse definisjonen: Jøde er den som er født av en jødisk mor eller har konvertert til jødedommen (Hove et al., 2015, s. 137; 2017, s. 207). $K R L E$-boka legger til at «noen retninger» aksepterer barn med jødisk far som er oppdratt jødisk, senere presisert til reformjødiske retninger (Wiik \& Waale, 2016, s. 236, 254). Mest inkluderende er Horisonter, som i tillegg til patrilineær avstamning og konversjon også nevner at «gjennom historien har det hendt at hele folkegrupper har gått over til jødedommen» (Holth \& Deschington, 2006, s. 48). Store spørsmål 8-10 adresserer ikke spørsmålet direkte. Det finnes enda mer inkluderende definisjoner, men dette blir ikke nevnt i bøkene. For eksempel regner staten Israel enhver person med minst en jødisk besteforelder som jøde i saker om immigrasjon, og mange moderne reformjødiske forsamlinger betoner ikke kravet om å være oppdratt jødisk.

En del norske barn har foreldre der den ene parten er jødisk, den andre ikke. Barna kan bli oppdratt helt eller delvis jødisk hjemme, men likevel kan de (og deres klassekamerater og lærere) risikere å få vite av læreboka at de ikke er jøder med mindre de konverterer, til tross for deres jødiske bakgrunn og oppdragelse. De jødiske menighetene i Oslo og Trondheim inkluderer ofte barn med jødisk far og ikke-jødisk mor, altså barn som ikke dekkes av lærebokdefinisjonen, i sin religionsundervisning.

Svaret på spørsmålet «Hvem er jødisk?» har for øvrig ikke bare konsekvenser for den enkelte jødiske elev som ikke faller inn under den ortodokse definisjonen; det vil også ha betydning for beregningen av antallet jøder, lokalt og globalt. Etter en mer omfattende definisjon vil USA, ikke Israel, være det landet i verden med den største jødiske befolkningen (jf. Pew Research Center, 2013, s. 24; Central Bureau of Statistics, 2019).

\section{Kosher}

Alle bøkene presenterer kashrut, tradisjoner for hva slags mat som regnes som kosher og kan spises, gjennom ortodokse briller. Dette presenteres som et sett distinkte regler som må overholdes, og det blir nevnt hva som ikke må spises (Holth \& Deschington, 2006, s. 50; 2008, s. 232; Hove et al., 2015, s. 143; 2017, s. 211; 2020, s. 77; Wiik \& Waale, 2016, s. 237-238). Siste utgave av Store Spørsmål overtar framstillingen av kosher fra den eldre boka for 10. trinn. Kosher nevnes to ganger, en gang i framstillingen av ortodoks jødedom og en gang i en faktaboks 
knyttet til omtalen av ultraortodoks jødedom, noe som ser ut til å implisere at kosher er et element i ortodoks praksis, inkludert haredi, men ikke i ikke-ortodokse retninger.

Alle bøkene erkjenner at ikke alle jøder overholder disse reglene, men de nevner ikke at mange jøder har andre oppfatninger av hva som er kosher, eller ser på kosher-reglene mer som sunnhetsråd som aldri var ment som bindende regler, eller som tidsbestemte og utdaterte. For eksempel erklærte «Pittsburghplattformen» fra 1885, et sentralt historisk dokument innen reformjødedommen:

We hold that all such Mosaic and rabbinical laws as regulate diet, priestly purity, and dress originated in ages and under the influence of ideas entirely foreign to our present mental and spiritual state. They fail to impress the modern Jew with a spirit of priestly holiness; their observance in our days is apt rather to obstruct than to further modern spiritual elevation (Pittsburgh Conference, 1885, \#4).

I nyere tid har mange reformjødiske institusjoner beveget seg i retning av mer tradisjonelle praksiser, for eksempel å avstå fra skalldyr eller å unngå blandinger av kjøtt og melk. Samtidig har det vært poengtert at elementer som kortreist, bærekraftig og «fair trade»-mat er viktige verdier som til tider kan trumfe kosherregler som er utbredt i ortodokse miljøer (se f. eks. Lyon, 2018). "Øko-kosher» og «etisk kosher» er begreper som kan komme i spill (se f.eks. Waskow, 1992; Zamore, 2011). Noen jøder følger tradisjonelle kosher-regler når det gjelder hvilke arter det er tillatt å spise, men stiller ikke krav om spesielle metoder for slakting eller fjerning av blod. Det er altså mange måter å praktisere kashrut på, men lærebøkene presenterer bare én av disse.

\section{Sabbaten}

Alle læreverkene presenterer sabbaten gjennom ortodokse briller. Store spørsmål 8 sier at «de som følger reglene strengt, skal ikke arbeide på sabbaten, heller ikke kjøre bil eller bruke elektriske apparater», uten å nevne andre oppfatninger av de omtalte reglene eller deres relevans i dag (Hove et al., 2015, s. 144). Både her og i Horisonter 8 heter det at alt til sabbaten må være forberedt på forhånd (Holth \& Deschington, 2006, s. 52). KRLE-boka spesifiserer at «innenfor ortodoks tradisjon er alle former for arbeid forbudt» (Wiik \& Waale, 2016, s. 239), men nevner ikke andre retningers forhold til sabbatobservans. Den nye utgaven av Store spersmål 8-10 nevner sabbaten bare to ganger, at det er fridag i Israel (Hove et al., 2020, s. 86), og at ortodokse jøder samles med familie og venner til sabbatsmåltid (s. 77) men hva med ikke-ortodokse jøder?

Generelt fraråder også konservativ jødedom de samme aktivitetene som ortodoks jødedom. Men i noen tilfeller tillates det, og til dels oppmuntres det 
til, både bruk av elektriske apparater (Heller, 2020; Lieber, 2020; Nevins, 2012) og bilkjøring (Weissman-Joselit, 2004) på sabbaten. For ortodoks jødedom er lærebøkenes utsagn akseptable som generaliseringer, selv om bildet også her er mer nyansert (Broyde, 1991; Greenberger \& Mor, 2016; Phillips, 2019). Når det gjelder reformjødedom har en derimot forstått mange av tradisjonene knyttet til sabbaten som ikke lenger bindende (Kaplan, 2013; Morris, 2020). Det har riktignok vært en viss dreining i tradisjonell retning i senere år. Men når Horisonter sier at religiøse jøder tar hviledagen på alvor, og deretter at andre jøder ikke følger reglene strengt (Holth \& Deschington, 2006, s. 52), ser det ut til å implisere at jøder uten en streng forståelse av sabbatsreglene ikke kan være religiøse, selv om religiøse jøder av ulike liberale denominasjoner kan ha mer liberale synspunkter på disse reglene, eller oppfatte dem som valgfrie.

$K R L E$-boka sier at «[k]vinnen i huset tenner sabbatlysene og velsigner dem» ved begynnelsen av sabbaten, og Horisonter og Store spørsmål 8 har tilsvarende utsagn (Wiik \& Waale, 2016, s. 239; Holth \& Deschington, 2006, s. 52; Hove et al., 2015, 144). Utsagnet ser ut til å gjelde alle jøder, men det forutsetter likevel en mer tradisjonell (ortodoks) praksis. Ikke-ortodokse bevegelsers egalitære karakter gjør at det generelt legges mindre vekt på at det er en kvinne som skal tenne sabbatslysene. Siden tidlig 1900-tall har det vært vanlig å tenne sabbatslys i synagogen i ikke-ortodokse retninger. Mens lystenning i synagogen i noen generasjoner erstattet lystenning i hjemmet innen reformjødiske bevegelser, vil mange reformfamilier i dag tenne lys både hjemme og i synagogen (Ellenson, 2004, s. 45-46).

Det heter i flere av bøkene at det er vanlig å oppsøke synagogen på sabbaten (Hove et al., 2015, s. 144; Wiik \& Waale, 2016, s. 239). Det er imidlertid store forskjeller i oppslutning mellom retningene. En undersøkelse fra USA viser at 74 $\%$ av ortodokse jøder oppsøker synagogen minst en gang i måneden, mens $39 \%$ av konservative jøder, $17 \%$ av reformjøder og bare $6 \%$ av jøder uten tilhørighet til noen retning gjør det samme (Pew Research Center, 2013, s. 76). Tall fra Israel viser samme tendens: $85 \%$ av haredi-jøder («ultraortodokse») deltar ukentlig i gudstjenester, $74 \%$ av dati-jøder («religiøse», som i denne statistikken mer eller mindre omfatter andre ortodokse jøder), $32 \%$ av tradisjonelle (men ikke nødvendigvis religiøse) jøder og bare $1 \%$ av sekulære jøder (Pew Research Center, 2016, s. 89). Også i Norge er det et mindretall av medlemmene som oppsøker synagogen hyppig.

\section{HVILKE ETNISKE/KULTURELLE GRUPPER FÅR REPRESENTERE DET JØDISKE?}

Her ser vi på bilder av mennesker og av Tora-ruller, på framstillingen av jødisk nærvær i Norge, og på kart over jødedommens utbredelse i verden. Disse temaene er valgt med tanke på å undersøke ulike modi i lærebøkenes representasjon av 
jødedom, i form av tekst, illustrasjoner og kart. Valgene kunne vært andre, en kunne for eksempel sett på bilder av synagogearkitektur og interiør.

\section{Illustrasjoner: Mennesker}

Det er verken mulig eller ønskelig å identifisere etnisiteten til de jødiske personene som finnes på fotografier i lærebøkene, men det er tydelig at disse bildene tar sikte på å vise fram et mangfold av bakgrunner. Alle bøkene har bilder av personer som kunne oppfattes som askenasiske, sefardiske og mizrahiske jøder, selv om elevene ikke blir introdusert for disse betegnelsene.

\section{Illustrasjoner: Tora-ruller}

Tora-ruller, håndskrevne kopier på pergament av de fem Mosebøkene, spiller en sentral rolle i jødiske ritualer. Men det er synlige forskjeller i utformingen av torarullene mellom askenasisk og sefardisk tradisjon. Det gjelder både håndskriftstiler og den fysiske utformingen. Askenasiske tora-ruller er festet til to atzei chajim («livstrær»), trestaver med håndtak oppe og nede. Når de ikke er i bruk, oppbevares de i et stykke tøy av fløyel eller lignende, gjerne rikt dekorert. Mizrahiske og de fleste sefardiske tora-ruller er som regel oppbevart i etui av tre eller metall, som kan åpnes slik at rullen ikke tas ut under høytlesningen.

Det er mange bilder av slike ruller i lærebøkene. Ti tora-ruller er avbildet $\mathrm{i}$ KRLE-boka. Samtlige har askenasisk utforming (Wiik \& Waale, 2016, s. 232-233, $236,248,259)$. Det samme gjelder rullene som er avbildet i Horisonter og i de to utgavene av Store spørsmål (Holth \& Deschington, 2006, s. 49, 60; Hove et al., 2015 , s. $138,146,147 ; 2020$, s. $70,76,77)$.

\section{Tekst: Første jøder i Norge}

Når kom de første jødene til Norge? «Mens kristendommen kom til Norge for over tusen år siden, har jøder vært en del av det norske samfunnet siden slutten av 1800-tallet», heter det i Store sporsmål (Hove et al., 2017, s. 205). Også Horisonter og KRLE-boka gjengir den alminnelige oppfatningen at jødisk nærvær i Norge først begynner i siste del av 19. århundre, etter opphevelsen av den såkalte «jødeparagrafen» i 1851 (Holth \& Deschington, 2006, s. 66; Wiik \& Waale, 2016, s. 242). Askenasiske jøder fra Øst-Europa ble snart den største gruppen av jødiske innvandrere, men historien går lenger tilbake og er mer sammensatt. I 1630 fikk sefardiske jøder fra Glückstadt i Holstein rett til å drive omreisende handel i Danmark og Norge. Ikke-sefardiske jøder måtte ha et særlig leidebrev for å drive slik virksomhet. Jøder kunne også etter søknad få bosette seg fast i noen byer i Danmark, men generelt ikke i Norge. Et unntak er en formulering i politivedtektene for Bergen fra 1710 som synes å forutsette at jøder kunne slå seg ned $\mathrm{i}$ byen med kongelig tillatelse. Det finnes noen få konkrete eksempler på at enkelte 
sefardiske jøder kan ha vært bosatt $i$ andre norske byer før 1814, $i$ alle fall periodevis (Mendelsohn, 1969, s. 11-31; Ulvund, 2014, s. 30-40). Den såkalte «jødeparagrafen» i 1814-grunnloven forbød alt jødisk nærvær i Norge. Den ble praktisert relativt strengt, men det fantes unntak. Jøder som hadde konvertert til kristendommen, som Hambro-familien i Bergen, var akseptert. Noen av disse har antakelig videreført en del jødiske tradisjoner (Koritzinsky, 1922, s. 58; Ulvund, 2014, s. 126-136; Sebak, 2008, s. 9-11). Forbudet ble også ved flere anledninger satt til side, blant annet når anstrengte norske statsfinanser hadde behov for økonomisk hjelp fra utenlandske finansinstitusjoner drevet av sefardiske jøder. Et skriv fra Justisdepartementet i 1844 fastslo at grunnlovsforbudet ikke gjaldt for sefardiske jøder, under henvisning til eldre praksis i Danmark-Norge. Etter hvert ble det igjen etablert en ordning med leidebrev (Mendelsohn, 1969, s. 57-60; Ulvund, 2014, s. 251-257).

Kart: Jødedommens utbredelse

Bruken av kart kan gi interessante innsikter i lærebøkenes oppfatning av religiøse tradisjoner (Thobro, 2014). Kart både i KRLE-boka og i Store spersmål viser antallet jøder i utvalgte europeiske og amerikanske land, Israel, Sør-Afrika, Australia og New Zealand (Wiik \& Waale, 2016, s. 251; Hove et al., 2017, s. 205; 2020, s. 74). Når teksten i læreboka i framstillingen av jødisk historie i nyere tid bare omtaler Europa, Israel, og Amerika, havner det jødiske nærværet i blant annet det øvrige Midt-Østen og Nord-Afrika utenfor horisonten. Store spørsmål nevner riktignok at Israel har tatt imot flyktninger fra mange land, men ikke hvilke (Hove et al. 2017, s. 209). Når holocaust/Shoah er nevnt tidligere i teksten, men ikke utdrivelsen fra arabiske land i det 20. århundre, kan elever og lærere sitte med inntrykk av at flyktningene kom fra Europa og ikke fra ikke-askenasiske hjemland som Irak, Marokko eller Jemen. Horisonter har på sin side ikke tilsvarende kart, men her nevnes det at «i lange tider har [jøder] hørt hjemme i Midtøsten, Europa, Afrika og Asia», og at dette mangfoldet nå er synlig i Israel (Holth \& Deschington, 2006, s. 48).

\section{Diskusjon}

Alle bøkene tematiserer altså mangfoldet av jødiske denominasjoner, men i mindre grad mangfoldet av etniske/kulturelle grupper. Dette er likevel ikke en hovedsak i tekstene. Mangfoldet introduseres som regel først avslutningsvis, nærmest som et appendiks.

I praksis viser det seg likevel at det er ortodoks observans og askenasisk kultur som får dominere framstillingen av jødedommen i lærebøkene, men uten at dette blir tydelig kommunisert. To begreper som kan belyse disse tendensene, er ortosentrisme og askenormativitet.

Ortosentrisme (ikke å forveksle med et lignende geometrisk begrep) er ennå 
ikke et veldefinert teoretisk begrep, men ordet forekommer ikke sjelden i interne diskusjoner om jødisk identitet som betegnelse på standpunkter som gjør ortodoks observans til målestokk for hva som kan regnes som jødedom, ofte da brukt av meningsbærere som ikke uten videre identifiserer seg med ortodoks tradisjon (se f. eks. Boyd, 2016, s. 21, 22). Her bruker vi det om essensialistiske framstillinger av jødedommen som gir ortodoks jødedom en hegemonisk posisjon.

Ikke-ortodokse bevegelser, særlig konservativ og reform-jødedom, utgjør mange steder flertallet av jøder tilsluttet en religiøs organisasjon, og det er også mange som ikke har noen slik tilknytning. En rapport fra 2013 anslår at $35 \%$ av den jødiske befolkningen i USA identifiserer seg med reformbevegelsen, $18 \%$ som konservative, $10 \%$ som ortodokse, $6 \%$ som tilhørende andre retninger, $30 \%$ som ikke tilhørende noen retning. Samtidig er det bare $31 \%$ av den jødiske befolkningen som har formelt medlemskap i en synagoge, uavhengig av retning (Pew Research Center, 2013, s. 10, 60). I Israel regner $49 \%$ av israelske jøder seg som sekulære, $29 \%$ som tradisjonelle (men ikke nødvendigvis religiøse), $13 \%$ som dati («religiøse») 9 \% som haredi («ultra-ortodokse» Pew Research Center, 2016, s. 67). Flertallet av jøder fra det post-sovjetiske Øst-Europa (enten de fortsatt er bosatt der eller er emigrert) oppfattes som «unattached to any Jewish venues» (Remennick, 2018, s. 121). Disse trendene er også synlige i Norge, hvor ikke alle medlemmer av de jødiske forsamlingene selv regner seg som ortodokse, og mange, kanskje de fleste, jøder ikke er tilsluttet en etablert jødisk forsamling (Herberger, upublisert).

Tilsvarende betegner askenormativitet representasjoner av jødedommen som framstiller askenasiske kulturelle praksiser som den normative jødiske kulturen. Også dette er et begrep som i utgangspunktet kommer fra interne debatter om jødisk identitet (flere viser til Katz, 2014), men det er i stigende grad tatt i bruk også i akademiske arbeider (se f. eks. Creese, 2019). Andre jødiske grupper har til dels radikalt forskjellige tradisjoner, oppfatninger om tradisjonell jødisk mat, språk, klesdrakt, musikk, litteratur, kunst, og også forståelser av jødiske religiøse normer og praksiser.

Norske læreplaner og læreverk er i bevegelse, bort fra en essensialistisk forståelse av religioner som monolittiske og sluttede systemer, noe som har vært et sentralt punkt i kritikken av «verdensreligioner-paradigmet», og i retning av en mer dynamisk forståelse av «levd religion». Denne studien tyder likevel på at det er et stykke å gå.

Det kan tenkes flere grunner til de implisitte tendensene til ortosentrisme og askenormativitet i lærebøkenes framstillinger av jødedommen. Lærebokforfattere må nødvendigvis gjøre utvalg, og det er ikke urimelig at norske forhold får være et viktig utvalgskriterium. Det har vært en viss ortodoks dominans i de organiserte norske jødiske menighetene i Oslo og Trondheim, og historisk sett har sammensetningen av den jødiske befolkningen i Norge i hvert fall fra 1880-tallet hatt 
en hovedsakelig askenasisk bakgrunn. Men mangfoldet er økende, ikke minst gjennom innvandring fra Israel, medlemmene av de jødiske forsamlingene følger ortodoks praksis i ulik grad, noen følger andre retninger, og også i Norge finnes det et betydelig antall jøder som ikke er tilsluttet en religiøs menighet.

De viktigste grunnene til manglende representasjon av mangfold er trolig ikke vrang vilje, men plassmangel og/eller mangelfull oversikt. Ortosentrisme og askenormativitet er ikke spesifikt norske fenomener, de eksisterer internasjonalt og er gjenstand for intern diskusjon i jødiske miljøer. Det kan godt tenkes at slike tendenser blir oversett selv om teksten gjennomgås av en konsulent med jødisk bakgrunn.

\section{SlutTord}

Hvordan jødisk mangfold framstilles i lærebøker, er viktig fordi det er med på å forme bildet av jødedom og jødiskhet hos alle norske barn og ungdommer. Men særlig viktig er det for elever med en jødisk bakgrunn. Elever som har en selvoppfattet jødisk identitet, men gjennom en patrilineær (altså individer med jødisk far, men ikke jødisk mor) eller annen ikke-ortodoks bakgrunn, elever fra jødiske familier som følger ikke-ortodokse jødiske praksiser eller ikke er praktiserende, og jødiske elever med annen kulturell bakgrunn enn den askenasiske kan oppleve seg usynliggjort eller implisitt framstilt som «dårlige jøder».

Plassen og tiden som er til disposisjon, setter naturligvis grenser for lærebokforfatteres og læreres muligheter til å øke mengden av undervisningsstoff. Det kan diskuteres hvilket detaljnivå som er nødvendig, hvilke denominasjoner som bør nevnes eksplisitt, eller hvor nødvendig det er for elevene å lære betegnelser som «askenasisk» og «sefardisk». Men kanskje kan disse betegnelsene også bidra til å gi bildet av jødedommen historisk dybde og geografisk bredde og slik bidra til et syn på religioner som anerkjenner «their complexity, internal diversity, and their varying interactions with culture», slik Jacksons «fortolkende tilnærming» legger opp til (Jackson, 2004, s. 4). Essensialistiske framstillinger kan stå i fare for å bidra til å sementere fordommer i stedet for å motvirke diskriminering (Rhodes et al. 2012; 2017).

Mye kan gjøres med enkle midler. Det mangfoldige utvalget av avbildede personer er nevnt som et vellykket eksempel i de eksisterende lærebøkene. En kan komme langt med en enda sterkere bevissthet $i$ utvalget av illustrasjoner, slik eksempelet med tora-rullene viser. Og en kan synliggjøre mangfold tydeligere i tekst, enklest ved å modifisere generaliseringer av «jødene» ved uttrykk som «en $\mathrm{del} /$ noen/mange jøder». 


\section{LitTERATUR}

Anker, T. (2017). På tide å si farvel til verdensreligionene? I M. von der Lippe \& S. Undheim (Red.), Religion i skolen. Didaktiske perspektiver på religions- og livssynsfaget (s. 25-34). Oslo: Universitetsforlaget.

Boyd, J. (2016). Searching for community: A portrait of undergraduate Jewish students in five UK cities. London: Institute for Jewish Policy Research.

Broyde, M. J. (1991). The use of electricity on Shabbat and Yom Tov. Journal of Halacha and Contemporary Society, 21. http://www.daat.ac.il/daat/english/ journal/broyde_1.htm.

Bråten, O. M. H. (2014). Bruk av lærebøker i RLE. I K. Fuglseth (Red.), RLE $i$ klemme. Ein studie av det erfarte RLE-faget (s. 173-197). Bergen: Fagbokforlaget.

Central Bureau of Statistics (2019). Media Release: Population of Israel on the Eve of 2020. https://www.cbs.gov.il/en/mediarelease/Pages/2019/ Population-of-Israel-on-the-Eve-of-2020.aspx.

Creese, J. (2019). Negotiating and Performing «Jewish Australian» Identity in South-East Queensland's Jewish Community: Creolization, National Identity and Power. Journal of International Migration and Integration. https://doi. org/10.1007/s12134-019-00714-8-

DellaPergola, S. \& Staetsky, L. D. (2020). Jews in Europe at the turn of the Millennium: Population trends and estimates. Insittute for Jewish Policy Research: European Jewish Demography Unit. https://www.jpr.org.uk/documents/JPR_2020. Jews_in_Europe_at_the_turn_of_the_Millennium.pdf

Ellenson, D. (2004). How the Modern Prayer Book Evolved. I L. A. Hoffman (Red.), Shabbat At Home. Woodstock, Vermont: Jewish Lights Publishing.

Greenberger, C. \& Mor, P. (2016). Should Sabbath Prohibitions Be Overridden to Provide Emotional Support to a Sick Relative? Rambam Maimonides Medical Journal, 7(3):e0023. https://doi.org/10.5041/RMMJ.10250.

Gundersen, K., Kristiansen, H. H., Samdal, A. G. \& Vestøl, J. M. (2014). Religion in textbooks and among young Buddhists, Hindus and Muslims: A comparative study. Acta didactica Norge, 8(1). https://doi.org/10.5617/ adno.1104.

Heller, J. (2020). Streaming Services on Shabbat and Yom Tov. Committee of Jewish Law and Standards of the Rabbinical Assembly. https://www.rabbinicalassembly.org/sites/default/files/2020-05/Streaming\%20on\%20Shabbat $\% 20$ and $\% 20$ Yom $\% 20$ Tov\%20Heller

Herberger, T. (upublisert). Re-evaluating Norway's Jewish Population: How Definitions and Methods Impact Population Estimates.

Holth, G. \& Deschington, H. (2006). Horisonter 8, Grunnbok: RLE for ungdomstrinnet. Oslo: Gyldendal.

Holth, G. \& Kallevik, K. A. (2008). Horisonter 10, Grunnbok: RLE for ungdomstrinnet. 
Hove, O., Jørgensen, J. A., Sandboe, M. \& Rasmussen, J. (2015). Store spørsmål 8: Kristendom, religion, livssyn og etikk. Oslo: Aschehoug.

Hove, O., Jørgensen, J. A. \& Sandboe, M. (2017). Store spørsmål 10: Kristendom, religion, livssyn og etikk. Oslo: Aschehoug.

Hove, O., Jørgensen, J. A., Sandboe, M. \& Rasmussen, J. (2020). Store spørsmål 8-10. Oslo: Aschehoug.

Jackson, R. (1997). Religious education: An interpretive approach. London: Hodder \& Stoughton.

Jackson, R. (2004). Studying Religious Diversity in Public Education: An Interpretive Approach to Religious and Intercultural Understanding. Religion and Education, 31(2), 1-20, https://doi.org/10.1080/15507394.2004.1001233 8.

Jackson, R. (2017). Veivisere. Retningslinjer og praksis for undervisning om religioner og ikke-religiøse livssyn i interkulturell utdanning. Strasbourg: Europarådet.

Jackson, R., Ipgrave, J., Hayward, M., Hopkins, P., Fancourt, N., Robbins, M., . . . McKenna, U. (2010). Materials used to teach about world religions in schools in England. Warwick: University of Warwick. https://doi.org/10.1080/155073 94.2010.486372.

Kaplan, D. E. (2013). The New Reform Judaism: Challenges and Reflections. Lincoln: University of Nebraska Press.

Katz, J. (2014). Learning to undo Ashke-normativity: A Jew in the Motherland. New Voices. https://newvoices.org/2014/10/22/learning-to-undo-ashkenormativity-a-jew-in-the-motherland/

Kirke- utdannings- og forskningsdepartementet. (1996) (L97). Laereplanverket for den 10-ärige grunnskolen. Oslo: Departementet.

Koritzinsky, H. M. (1922). Jødernes historie i Norge: Henrik Wergelands kamp for jødesaken. [Kristiania].

Lewis, J. R. \& Andreassen, B.-O. (2014). Textbook gods: Genre, text and teaching religious studies. Sheffield: Equinox.

Lieber, A. (2020). Networked Individuals: The virtual reality of the sabbath in twenty-first century American Judaism. Religion in the Age of Digitalization: From New Media to Spiritual Machines. London: Routledge. https://doi. org/10.4324/9780367809225.

Lyon, D. A. (2018). The dietary laws: Fitness for a life well-lived. https:// reformjudaism.org/learning/torah-study/shmini-ii/dietary-laws-fitness-lifewell-lived/.

Mendelsohn, O. (1969). Jødenes historie i Norge gjennom 300 år. Bind 1. Oslo: Universitetsforlaget.

Midttun, A. (2014). Biter og deler av islam. Norsk pedagogisk tidsskrift, 98(5), 329-340. 
Morris, L. A. (2020). What Do We Mean When We Say, «We Are Not Halachic»? CCAR Journal: The Reform Jewish Quarterly 67(2), 9-16.

Nevins, D. S. (2012). The Use of Electrical and Electronic Devices on Shabbat. Committee on Jewish Law and Standards of the Rabbinical Assembly. https://www.rabbinicalassembly.org/sites/default/files/public/halakhah/ teshuvot/2011-2020/electrical-electronic-devices-shabbat.pdf

Pew Research Center (2013). A Portrait of Jewish Americans: Findings from a Pew Research Center Survey of U.S. Jews. https://www.pewforum.org/2013/10/01/ jewish-american-beliefs-attitudes-culture-survey/.

Pew Research Center (2016). Israel's Religiously Divided Society. https://www. pewforum.org/2016/03/08/israels-religiously-divided-society/.

Phillips, R. (2019). An Ambivalent Jewishness: Half Shabbos, the Shabbos App, and Modern Orthodoxy. I J. Fewkes (Red.), Anthropological Perspectives on the Religious Uses of Mobile Apps (s. 43-59). New York: Palgrave Macmillan. https://doi.org/10.1007/978-3-030-26376-8_3.

Pittsburgh Conference (1885). Declaration of Principles. https://www.ccarnet.org/ rabbinic-voice/platforms/article-declaration-principles/.

Remennick, L. (2018). Choosing One or Being Both: The Identity Dilemmas of Russian-Jewish Mixed Ethnics Living in Russia and in Israel. East European Jewish affairs, 48(2), 118-138. https://doi.org/10.1080/13501674.2018.14751 76.

Rhodes, M., Leslie, S. J. \& Tworek, C. M. (2012). Cultural transmission of social essentialism. Proceedings of the National Academy of Sciences, 109(34), 1352613531.

Rhodes, M., Leslie, S. J., Saunders, K., Dunham, Y. \& Cimpian, A. (2017). How does social essentialism affect the development of inter-group relations? Developmental Science. doi.org/10.1111/desc. 12509

Sebak, P. K. (2008). «-vi blir neppe nogensinne mange her»: Jøder i Bergen 1851-1945. Bergen: Vigmostad \& Bjørke.

Skjelbred, D., Askeland, N., Maagerø, E. \& Aamotsbakken, B. (2017). Norsk larebokhistorie: Allmueskolen - folkeskolen - grunnskolen 1739-2013. Oslo: Universitetsforlaget.

Tallaksen, I. M. \& Hodne, H. (2014). Hvilken betydning har læremidler i RLE-faget? Norsk pedagogisk tidsskrift, 98(5), 352-363.

Thobro, S. A. (2008). Representasjoner av buddhisme og hinduisme: En diskursanalyse $i$ postkolonialt perspektiv av laerebøker i religionsfaget for gymnas/videregående skole. Masteravhandling (religionsvitenskap), Universitetet i Bergen, Bergen.

Thobro, S. A. (2014). Cartographic representations of religion(s) in Norwegian textbooks. I J. R. Lewis \& B.-O. Andreassen (Red.), Textbook gods: Genre, text and teaching religious studies (s. 157-176). Sheffield: Equinox. 
Thomas, A. \& Rolin, A. (2019). Reading religion in Norwegian textbooks: Are individual religions ideas or people? British Journal of Religious Education, 41(1), 41-53. https://doi.org/10.1080/01416200.2018.1484691.

Ulvund, F. (2014). Fridomens grenser 1814-1851: Handhevinga av den norske «jødeparagrafen». Oslo: Scandinavian Academic Press.

Utdanningsdirektoratet (2015). Lareplan $i$ kristendom, religion, livssyn og etikk (KRLE) (RLE01-02). https://www.udir.no/k106/RLE1-02.

Utdanningsdirektoratet (2020). Lareplan $i$ kristendom, religion, livssyn og etikk (KRLE) (RLE01-03). https://www.udir.no/lk20/rle01-03.

Waskow, A. (1992). What is Eco-Kosher? Jewish Quarterly, 39(4), 5-10. https:// doi.org/10.1080/0449010X.1992.10705881.

Weissman-Joselit, J. (2004). In the driver's seat: Rabbinic authority in postwar America. I J. Wertheimer (Red.), Jewish Religious Leadership: Image and Reality (vol. 2, s. 659-670). New York: Jewish Theological Seminary.

Wiik, P. \& Waale, R. B. (2016). KRLE-boka 8-10. Oslo: Cappelen Damm.

Winje, G. (2011). Når «de Andre» rykker nærmere: Om 1900-tallets lærebøker i kristendomskunnskap. I D. Skjelbred \& B. Aamotsbakken (Red.), Norsk lerebokhistorie - en kultur-og danningshistorie 3 (s. 139-157). Oslo: Novus.

Wintersgill, B. (2014). Researching materials used to teach about world religions in schools in England. I: J. R. Lewis \& B.-O. Andreassen (Red.), Textbook gods: Genre, text and teaching religious studies (s. 98-116). Sheffield: Equinox.

Zamore, M. (Red.). (2011). The Sacred Table: Creating a Jewish Food Ethic. New York, NY: CCAR Press. 